〔日農医誌 65巻 5 号 963～968頁 2017. 1]

\title{
研究報告：
}

\section{地域在住高龃者におけるフレイルと 認知症の精査希望との関連}

\section{白石卓 也*}

高齢者の望ましくない転帰を招くフレイルは，認知症と関連があると報告されている。 高齢者のフレイルを評価することは，高齢者が認知症となっても住み慣れた地域で尊厳の ある生活を送れるような支援体制づくりに役立つのではないかと考えた。しかし，本邦で フレイルと認知症との関連について検討した報告はほとんどない。そこで本研究では, フ レイルと認知症，さらに認知症の精査希望との関連について検討した。平成 27 年 11 月から 平成 28 年 4 月の間に要介護認定申請した高齢者 49 名を対象に, 認知症既往や認知症の精査 希望があるかといったアンケート調査を実施し，フレイルを評価した。認知症既往のない 高齢者をフレイル有無の 2 群に分け, 年齢, 性別, 改訂長谷川式簡易知能評価スケール (HDS-R) の点数, 認知症疑いおよび認知症の精査希望について比較検討した。その結果, 認知症既往のない高齢者は 29 名であり, フレイルあり群は13名で, フレイルなし群は16名 であった。その 2 群間の比較では, HDS-Rの点数, 認知症疑いおよび認知症の精査希望 において有意差を認めた。本研究から，要介護認定申請時に認知症既往のない高齢者がフ レイルであると，認知症の可能性は高く，認知症が疑われても精査を希望しないという結 果が示された。高齢者のフレイルを評価することは, 認知症やその精査希望の有無の指標 となり，高齢者やその家族に対する認知症の支援体制づくりの一助となると考えられた。

(1)要介護認定 (2)認知機能 (3)認知症 (4)高齢者 (5)フレイル

緒 言

本邦の平均寿命は延長し高齢者数は増え, そ れに伴い認知症有病者数も増加している。団塊 の世代の人たちが後期高齢者となる 2025 年の認 知症有病者数は約 700 万人となり, その後もさ らなる高齢者数の増加に伴って認知症有病者数 は増え続けると推計されている1)。そのため, 高齢者が認知症となっても住み慣れた地域で尊 厳のある生活を送れるような支援体制づくりが 必要とされている。

* = 370-1616 群馬県多野郡上野村大字乙父630-1 上野村へき地診療所 (受付：2016年 6 月 7 日)
高齢者の望ましくない転帰を招く危険因子と して注目されているフレイルは ${ }^{2 \sim 5}$, 認知症と 関連があると報告されている ${ }^{6)}$ 。そのため, 高 齢者のフレイルを評価することは，高齢者やそ の家族に対する認知症の支援体制づくりに役立 つのではないかと考えた。しかし，本邦でフレ イルと認知症との関連について検討した報告は ほとんどない。そこで本研究では, フレイルと 認知症, さらに認知症の精査希望との関連につ いて検討した。

\section{対象と方 法}

対象者は, 平成 27 年 11 月から平成 28 年 4 月の 間に当地域で要介護認定申請した高齢者49名と した。対象者に認知症既往と認知症の精査希望 
があるかといったアンケート調査を実施し，フ レイルを評価した。アンケートは要介護認定申 請を受け付けする担当職員から要介護認定申請 時に申請した本人もしくはその家族へ配布して もらった。倫理的配慮として，配布時に調査の 趣旨や参加は自由意志であることを口頭で説明 し，アンケートの回収をもって調查の同意を得 られたものとした。

認知症は, 改訂長谷川式簡易知能評価スケー ル (Hasegawa's Dementia Scale for Revised; 以下 HDS-R と略記）を使い評価した。HDS-R が20点以下を認知症疑いと定義した7)。フレイ ルは, 要介護認定申請時の診察および本人や家 族から聴取した日常生活動作 (Activities of Daily Living ; 以下 ADL と略記) をもとに評 価した。フレイルの定義や診断基準について多 くの議論が行なわれているが，コンセンサスは 得られていない。そのため, 臨床で使いやすい clinical frailty scale（以下 CFS と略記）を使 いフレイルを評価した。CFSは 9 段階で判定 され，手段的 $\mathrm{ADL}$ が困難となった段階である 5 以上をフレイルと定義した ${ }^{8)}$ 。

認知症既往のない高齢者を CFS が 5 以上の フレイルあり群と, CFS が 5 未満のフレイル なし群の 2 群に分け，年齢，性別，改訂長谷川 式簡易知能評価スケールの点数, 認知症疑いお よび認知症の精査希望について比較検討した。 データは, 中央值（四分位範囲）もしくは対象 者数（\%)で示した。連続変数の統計学的差は the Mann-Whitney U test を用い，カテゴリー データの統計解析には Fisher's exact probabil- ity testを用いた。なお，統計解析には EZR を用い9，統計的有意水準は $5 \%$ 未満とした。

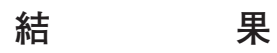

アンケートは46名から得られ, 回収率は 93.9\%であった。その中で要介護認定申請時に 認知症と診断されていない高齢者は29名（男性 8 名，女性21名）であった。CFSの定義に従 いフレイル有無の 2 群に分けたところ, フレイ ルあり群は 13 名（男性 4 名，女性 9 名）で，フ レイルなし群は16名（男性 4 名, 女性 12 名）で あった。フレイルあり群における年齢の中央值 は86 (78.5〜87.3) 歳, HDS-R は19 (14.0〜21.0) 点, 認知症疑いは 8 名で全体の $61.5 \%$ を占め, 精査希望者は 5 名で全体の $38.5 \%$ を占めてい た。一方，フレイルなし群における年齢の中央 值は87（85.0～92.0）歳, HDS-R は25（22.8～ 26.3）点, 認知症疑いは 2 名で全体の $12.5 \%$ を 占め, 精査希望者は 12 名で全体の $75.0 \%$ を占め ていた。フレイルあり群およびフレイルなし群 の 2 群間の比較では, HDS-Rの点数, 認知症 疑いおよび認知症の精査希望において統計学的 有意差を認めた（表 1 ）。アンケート回答者は, 子供が $47 \%$ ，嫁が $20 \%$ ，本人および夫が $13 \%$ ， 担当ケアマネージャーが 7 \%であった（図 1 )。

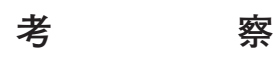

要介護認定申請時に認知症既往のない高齢者 において，フレイルと認知症疑いとの間に有意 な関連が認められた。従来の報告によれば，フ レイルと判定される人は認知症である割合が高

表 1。各群における対象者の内訳

\begin{tabular}{lcrl}
\hline & フレイルあり群 $(\mathrm{n}=13)$ & フレイルなし群 $(\mathrm{n}=16)$ & 有意差 \\
\hline 年齢 (歳) & $86(78.5 \sim 87.3)$ & $87(85.0 \sim 92.0)$ & $\mathrm{ns}$ \\
女性 (人) & $9(69.2 \%)$ & $12(75.0 \%)$ & $\mathrm{ns}$ \\
$\mathrm{HDS}-\mathrm{R}$ の点数 (点) & $19(14.0 \sim 21.0)$ & $25(22.8 \sim 26.3)$ & $* *$ \\
認知症疑い (人) & $8(61.5 \%)$ & $2(12.5 \%)$ & $*$ \\
精査希望者 (人) & $5(38.5 \%)$ & $12(75.0 \%)$ & $*$ \\
\hline
\end{tabular}

HDS-R: Hasegawa's Dementia Scale for Revised, ns: no significance, ${ }^{* *}: \mathrm{p}<0.01, \quad * \mathrm{p}<0.05$ 年齢および HDS-R の点数は中央值（四分位範囲）で示した。女性，認知症疑いおよび 精査希望者は対象者数（\%）で示した。 


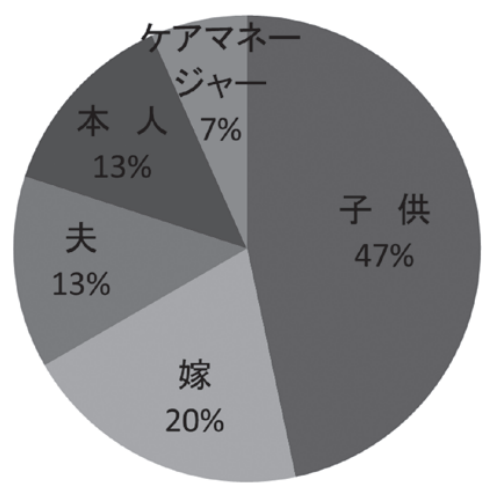

図 1.アンケート回答者の内訳 アンケートの回答者は主に子供や嫁といった介 護者となる家族であった。

いとされている ${ }^{6)}$ 。フレイルと認知症との関連 は，脳血管性認知症のみを増やす ${ }^{10,11)}$ ，アルッ ハイマー型認知症を含めた認知症全体を増や す12,13) など一定の結果は得られていないが，フ レイルと認知症は密接に関連していると多数報

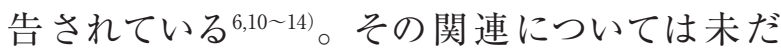
不明であるが，炎症や酸化ストレスによる組織 障害，低栄養，テロメアの短縮などさまざまな 機序が推測されている ${ }^{15,16)}$ 。本邦において, 認 知症が悪化すると ADL も低下するといった認 知症の重症度とADLとの関連 ${ }^{17,18)}$ やフレイル と軽度認知障害との関連 ${ }^{19)}$ を示した報告はあ るが，フレイルと認知症との関連について検討 した報告はほとんどなかった。本研究におい て，フレイルと認知症疑いとの間に有意な関連 を認め，高齢者のフレイルを評価することは認 知症を疑う契機となると考えられた。

要介護認定申請時に高齢者がフレイルである と，認知症が疑われても精査を希望しないとい う結果が示された。その回答者は主に子供や嫁 などの介護者となる家族であった。本邦の認知 症施策として，認知症の早期発見・早期対応が 掲げられているが，本人やその家族への啓発活 動のみでは早期受診につながらないといった臨

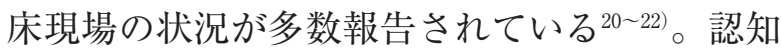
症の初期症状の多くは必ずしも認知症特有の症 状ではなく，他の疾患や老化による影響と混同 されやすいため，早期受診につなげるためには 高度な知識が求められるといった問題もあ
る ${ }^{23)}$ 。そのため，要介護認定申請時に行なう HDS-R を利用し，認知症が疑われた場合に希 望があれば精查し, 認知症の早期発見・早期対 応につなげようと考えた。要介護認定申請する 高齢者はフレイルである場合が多いため, 認知 機能が低下している可能性が高く, 介入する余 地があると考えていた。しかし，本研究ではフ レイル高齢者であると認知症が疑われても精査 を希望しないという結果が示され，高齢者の $\mathrm{ADL}$ は認知症の早期受診を左右する因子と なっていると考えられた。

今まで認知症を指摘されていなかった高齢者 において認知機能の低下を認めた場合，医療者 は治療可能な認知症であるか見極める必要があ る。治療可能な認知症は, 慢性硬膜下血腫, 甲 状腺機能低下症などあるが, 病歴, 既往歴, 職 歴，生活歴および診察などからそのような疾患 を疑った場合は，早期発見・早期対応していか なければならず，本人や家族にその旨を説明 し, 要介護認定申請時に精査希望なくても認知 症の原因検索をすすめるべきである。しかし， 治療可能な認知症でなければ，精査希望ない本 人や家族へ慎重に対応しなければならないと考 えられる。現在, 根本的な認知症治療薬が存在 しない状況下では，医療者側の都合で安易に早 期発見・早期対応していくことは，認知症と診 断をうける本人や家族に落胆や失望, 絶望を与 えかねないといった指摘がある ${ }^{24)}$ 。欧米諸国で は早期発見・早期対応に対する反省があり，そ れに変わり適切な時期における診断と対応とい う考えが広まりつつある24)。本邦においても， 早期発見・早期対応に固執することなく欧米諸 国の反省を生かし，認知症を認めた高齢者のお かれた家庭や地域，社会的状況を踏まえた医 療・介護等を提供していくことが大切だと考え られる。

高齢者のフレイルを評価することは，高齢者 やその家族に対する認知症の支援体制づくりの 一助となる可能性がある。フレイルは認知症と

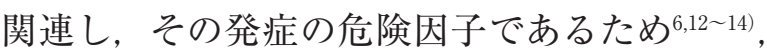
要介護認定申請時に認知症がなくてもフレイル 高齢者はフレイルのない高齢者と比べ，認知機 
能が低下しやすい。認知症が疑われ精査を望ま ない高齢者と同様に，フレイルと判定された高 齢者に対しても地域における医療介護従事者間 で情報を共有しておけば，適切な時期に認知症 の診断や対応ができる可能性がある。認知症高 齢者だけでなくフレイル高齢者に注意し，認知 症に伴う種々の問題が起きつつあるときや顕在 化した直後に支援できれば，本人や家族など周 囲の人への負担軽減につながると考えられた。

本研究は要介護認定申請者を対象とした調査 であり，一般住民に対して本研究の結果をその まま当てはめることができない。また，限られ た地域で実施した調査であることから結果を普 遍化するには限界がある。今後は，本邦におけ るフレイルと認知症との関連を明らかにするた めに, 対象者や地域を拡大した調査が必要であ る。

\section{結 論}

要介護認定申請時に認知症既往のない高齢者 がフレイルであると，認知症の可能性は高く， 認知症が疑われても精査を希望しないという結 果が示された。認知症が疑われ精査を望まない 高齢者と同様に，フレイルと判定された高齢者 に対しても地域における医療介護従事者間で情 報を共有しておけば，適切な時期に認知症の診 断や対応ができる可能性がある。高齢者のフレ イルを評価することは，認知症やその精査希望 の有無の指標となり，高齢者やその家族に対す る認知症の支援体制づくりの一助となると考え られた。

\section{著者のCOI 開示}

本論文発表内容に関連して特に申告なし。

\section{文献}

1 ）下村裕見子, 大石 智, 廣岡孝陽, 他. 地域の援 助職が感じている認知症ケアを実践する上での課 題とその背景要因に関する研究一相模原市のアン ケート調查から考察する一。 日クリニカルパス会 誌 $2016 ； 18(1) ： 10-18$.

2 ) Clegg A, Young J, Iliffe S, et al. Frailty in elderly people. Lancet $2013 ; 381: 752-762$

3 ) Fried LP, Tangen CM, Walston J, et al. Frailty in older adults: evidence for a phenotype. $\mathrm{J}$ Gerontol A Biol Sci Med Sci. 2001 ; 56 : M146156.

4 ）白石卓也. 中山間地域の診療所における高齢者市 中肺炎患者とフレイルの検討。日農医誌 2015； 64(2) : 55-160.

5 ) 白石卓也. 中山間地域の高齢者におけるフレイル と救急搬送後の転帰の 関連性. Kitakanto Med J. $2015 ; 65(1): 39-44$.

6 ) Kulmala J, Nykänen I, Mänty M, et al. Association between frailty and dementia: a population-based study. Gerontology 2014 ; 60(1) : 16 -21 .

7 ) 加藤伸司, 下坦 光, 小野寺敦志, 他. 改訂長谷 川式簡易知能評価スケール（HDS-R）の作成. 老年精医誌 $1991 ； 2$ (11)：1339-1347.

8 ) Rockwood K, Song X, MacKnight C, et al. A global clinical measure of fitness and frailty in elderly people. CMAJ $2005 ; 173(5)$ : 489-495.

9 ) Kanda Y. Investigation of the freely available easy-to-use software 'EZR' for medical statistics. Bone Marrow Transplant 2013 ; 48(3) : 452458.

10) Avila-Funes JA, Carcaillon L, Helmer C, et al. Is frailty a prodromal stage of vascular dementia? Results from the Three-City Study. J Am Geriatr Soc. 2012 ; 60(9) : 1708-1712.

11) Solfrizzi V, Scafato E, Frisardi V, et al. Frailty syndrome and the risk of vascular dementia: the Italian Longitudinal Study on Aging. Alzheimers Dement 2013 ; 9(2) : 113-122.

12) Wilkins CH, Roe CM, Morris JC, et al. Mild physical impairment predicts future diagnosis of dementia of the Alzheimer's type. J Am Geriatr Soc. 2013 ; 61(7) : 1055-1059.

13) Song X, Mitnitski A, Rockwood K. Nontraditional risk factors combine to predict Alzheimer disease and dementia. Neurology $2011 ; 77(3)$ : $227-234$.

14) Boyle PA, Buchman AS, Wilson RS, et al. Physical frailty is associated with incident mild cognitive impairment in community-based older persons. J Am Geriatr Soc. 2010 ; 58(2) : 248255.

15) De Martinis M, Franceschi C, Monti D, et al. Inflammation markers predicting frailty and mortality in the elderly. Exp Mol Pathol. 2006 ; $80(3): 219-227$.

16) Mulero J, Zafrilla P, Martinez-Cacha A. Oxidative stress, frailty and cognitive decline. J Nutr 
Health Aging. $2011 ; 15(9): 756$-760.

17）本間 昭. 痴呆の行動評価. 老年精医誌 1990 ; 1 (4) : 403-424.

18）横井輝夫, 岡本圭左, 櫻井 臣, 他. 痴呆性高齢 者の認知機能障害と ADL 重症度との関連. 理学 療法学 2003；18(4)：225一228.

19）佐治直樹, 荒井秀典, 櫻井 孝, 他. フレイルと サルコペニア一認知症との新たな接点一。 日本臨 牀 2016；74(3)：505一509.

20）本間 昭. 痴呆性高齢者の介護者に扔ける痴呆に 対する意識・介護・受診の状況. 老年精医誌 $2003 ； 14(5) ： 573-591$.

21）木村清美，相場健一，小泉美佐子．認知症高齢者
の家族が高齢者をもの忘れ外来に受診させるまで のプロセス; 受診の促進と障壁. 日認知症ケア会 誌 $2011 ； 10(1): 53$-67.

22）品川俊一郎, 中山和彦. 認知症患者の早期受診 · 介入の障害となる要因に関する検討；一般市民・ かかりつけ医・介護支援専門員のアンケート調査 より．老年精医誌 $2007 ； 18(11) ： 1224-1233$.

23）杉山 京, 中尾竜二, 澤田陽一, 他. 一般地域住 民に扔ける家族に認知症症状がみられた際の受診 促進意向と認知症の知識量との関連. 老年精医誌 2012 ; 23(12)：1453-1462.

24）松下正明. アルッハイマー病早期診断の功罪. 老 年精医誌 $2015 ； 26(4) ： 413$-418. 


\title{
Relationship between Frailty and Expectations for Comprehensive Dementia Assessment in Elderly People in Rural Areas
}

\author{
Takuya SHIRAISHI*
}

The relationship between frailty and expectations for comprehensive dementia assessment were investigated in this survey study involving the elderly who required certification for longterm care provision. The participants were 29 elderly individuals who were divided into 2 groups according to whether they were frail or not. They had not been diagnosed with dementia before certification for long-term care provision. Their cognitive function was assessed and those with suspected dementia completed a questionnaire survey on their expectations for comprehensive assessment of dementia. Thirteen participants were frail and 16 were not. The findings of "suspicion of dementia" and "expectations for comprehensive assessment of dementia" showed significant difference between the groups. Frailty may be correlated with suspected dementia but not expectations for comprehensive assessment of dementia. Our study suggests that evaluating frailty in the elderly could contribute to creating a support system for those with dementia and their families.

*Uenomura Remote Place Clinic, Gunma, Japan 